Нанопрепараты

\title{
ФОТОСИНТЕТИЧЕСКАЯ ПРОДУКТИВНОСТЬ И СТРУКТУРА УРОЖАЯ ЯРОВОЙ ПШЕНИЦЫ ПОД ВЛИЯНИЕМ НАНОКРЕМНИЯ В СРАВНЕНИИ С БИОЛОГИЧЕСКИМ И ХИМИЧЕСКИМ ПРЕПАРАТАМИ
}

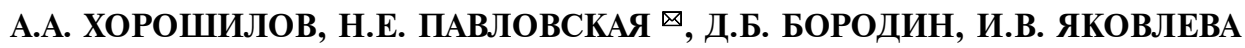

\begin{abstract}
Пшеница широко используется как пищевая, техническая и кормовая культура. Увеличение урожайности культуры возможно за счет смягчения последствий биотических и абиотических стрессов посредством различных технологий, включающих применение микроэлементов и регуляторов роста. Одним из перспективных препаратов представляется микроудобрение Нанокремний (ООО «НаноКремний», Россия) - экологически чистый продукт, содержащий в своей основе $50 \%$ чистого кристаллического кремния с частицами коллоидного размера. В настоящей работе впервые было показано положительное влияние препарата Нанокремний на фотосинтетический потенциал и величину чистой продуктивности фотосинтеза, синтез хлорофилла, каротиноидов и сахаров, а также преимущество этого микроудобрения перед пестицидом Винцит, КС и экспериментальным биопрепаратом. Под влиянием Нанокремния изменилась структура урожая яровой пшеницы: увеличилось число продуктивных стеблей, колосьев и масса 1000 зерен. Нашей целью было изучение влияния препарата Нанокремний на фотосинтетическую продуктивность и структуру урожая яровой пшеницы в условиях Орловской области и сравнение его действия с таковым химического пестицида и биоактивного препарата. Полевые опыты проводили в 2016-2019 годах (ФГБУ ФНЦ зернобобовых и крупяных культур, пос. Стрелецкое, Орловская обл.) на яровой пшенице (Triticum aestivum L.) сорта Дарья. В эксперименте было два контрольных (вода и химический пестицид Винцит, КС) и два опытных (биопрепарат на основе биофлаваноидов гречихи и препарат Нанокремний) варианта. Во всех вариантах семена перед посевом замачивали в течение 2 ч. Обработку по вегетации проводили дважды опрыскиванием вегетирующих растений в фазу кущения и выхода в трубку. Энергию прорастания и всхожести семян определяли по ГОСТ 12038-84, развитие семенной инфекции - по ГОСТ 12044-93. Фенологические наблюдения выполняли в фазы 2-3-го листа, кущения, выхода в трубку, колошения, цветения, молочной спелости и полной спелости зерна. Оценивали фотосинтетический потенциал (ФП) и чистую продуктивность фотосинтеза (ЧПФ), измеряли площадь листьев и содержание пигментов в растениях. Установлено, что предпосевная обработка семян яровой пшеницы Нанокремнием способствовала увеличению энергии прорастания на $18,5 \%$, всхожести - на $5,5 \%$ (р < 0,05) по сравнению с контрольными вариантами. Превосходство по высоте растений в варианте с Нанокремнием отразилось на числе листьев яровой пшеницы, сохранявшихся до конца вегетационного периода, что указывает на большую продолжительность жизни листа в опытных вариантах по сравнению с контрольными. Наиболышей площади листьев яровая пшеница достигала в варианте с Нанокремнием в период колошенияцветения: показатель был на 20,0 \% больше, чем в контроле (вода). При использовании биопрепарата эта разница составила 14,6\%, пестицида Винцит, КС - 8,3\%. Фотосинтетический потенциал по вариантам контроль (вода), Винцит, КС, Нанокремний, биопрепарат составлял соответственно 633360, 686022, 1560384 и 1104894 м² сут/га. Показатели ЧПФ при обработке Нанокремнием были выше контрольных на 60-80 \% (вода) и 22,2 \% (Винцит, КС). Наибольшее количество хлорофиллов и каротиноидов в растениях образовывалось в фазу колошение-цветение. Под влиянием Нанокремния и биопрепарата синтез пигментов увеличился по сравнению с контрольными вариантами на 20-30\%. Нанокремний способствовал увеличению синтеза сахаров в процессе фотосинтеза в меньшей степени, чем биопрепарат, что можно объяснить разницей в перераспределении ассимилятов и большим накоплением белков. Показаны незначительные преимущества обработки Нанокремнием перед биоактивным препаратом по числу зерен в колосе и массе 1000 семян. Под влиянием обработки Нанокремнием число продуктивных стеблей увеличивалось на 33,7 , колосьев - на 38,7, масса колоса - на 26,8, число зерен в колосе - на 19,2, масса 1000 семян - на 19,7 \% по сравнению с контролем (вода). Показатели по биопрепарату были несколько ниже, чем по Нанокремнию, но выше контрольных. Урожайность пшеницы на протяжении 4 лет под влиянием обработки Винцитом, КС увеличивалась на 8 \% по сравнению с контролем без обработки, а при использовании Нанокремния и биопрепарата ее прирост составил 9,0-16,6 \%.
\end{abstract}

Ключевые слова: яровая пшеница, Нанокремний, биопрепарат, энергия прорастания, всхожесть, чистая продуктивность фотосинтеза, пигменты, структура урожая.

Пшеница занимает 30,3 \% всех посевных площадей под зерновыми 
и широко используется как пищевая, техническая и кормовая культура (14). Ее можно выращивать в широком диапазоне климатических условий и почв (5-7), однако М. Trnka с соавт. (8) представили анализ, учитывающий ряд неблагоприятных погодных явлений, которые могут существенно повлиять на урожайность пшеницы в Европе. Изменение климата приведет к сокращению производства основных зерновых культур, за исключением проса (9). Увеличение урожайности пшеницы может быть достигнуто посредством смягчения последствий биотических и абиотических стрессов при использовании различных технологий.

В последние десятилетия научное сообщество и коммерческие предприятия уделяют значительное внимание растительным биостимуляторам и микроэлементам, в частности кремнию. Кремний ослабляет негативное воздействие абиотических стрессов (токсичность металлов, соленость, водный стресс и температура) и обладает способностью уменьшать биотический стресс (10-12). Применение кремниевых удобрений существенно повышает устойчивость растений к болезням и вредителям. Под влиянием кремния включаются такие защитные механизмы, как синтез фитоалексинов, ферментов антиоксидантной защиты, передача сигналов жасмоновой кислоты (13-15). Положительный эффект кремниевых удобрений показан на различных почвах при выращивании риса, сахарного тростника, ячменя, сорго, кукурузы, пшеницы, овса, ржи, подсолнечника, бобов, кормовых бобов, сои, клевера, люцерны, проса, томатов, огурцов, табака, сахарной свеклы, лимонов, мандаринов, винограда, яблок, дынь (16-18). Под влиянием кремния усиливается интенсивность и продуктивность фотосинтеза. Между тем вклад признаков, определяющих продукционный процесс у растений, который осуществляется благодаря функционированию фотосинтезирующей системы, до сих пор не ясен (19).

Дополнительный фотосинтез может происходить за счет увеличения его дневной продолжительности или увеличения площади листа. При этом одним из следствий повышения фотосинтеза у зерновых культур считают увеличение потенциального числа зерен и их размера $(6,20,21)$.

Перспективный препарат, который можно использовать на зерновых культурах, - микроудобрение Нанокремний (ООО «НаноКремний», Россия). Это экологически чистый продукт, содержащий в своей основе $50 \%$ чистого кристаллического кремния в виде частиц коллоидного размера. Для стабилизации частиц в нем используется полиэтиленгликоль (пищевая добавка Е1521), а также $6 \%$ железа, $1 \%$ меди, 0,5\% цинка, $20 \%$ гуминовых кислот, 8 \% фульвокислот, $0,02 \%$ кальция, $0,01 \%$ бора. В отличие от обычного кремния, Нанокремний - это препарат с частицами активного кремния размером от 5 нм, без дополнительных примесей, что позволяет растениям усваивать его на $100 \%$ (22). Исследования, проведенные на яровой пшенице (22-24), озимой пшенице (25) и озимом ячмене (26), показали, что Нанокремний способствовал увеличению озерненности колосьев и повышению урожайности на 34-35 \% при обработке семян и двукратном опрыскивании растений.

Регуляция и модификация физиологических процессов в растениях, а также оптимизация эффективности использования солнечного света на протяжении всего цикла выращивания - актуальная задача. Несмотря на то, что при фотосинтезе образуется сухое вещество, найти зависимость между этим процессом и величиной урожая весьма сложно. Повышение эффективности фотосинтеза и урожая сельскохозяйственных растений достигается прежде всего посредством генетического улучшения сортов, а 
также подбором сортовой агротехники, технологии возделывания, регуляторов роста и развития растений.

В настоящей работе впервые было показано положительное влияние препарата Нанокремний на величину фотосинтетического потенциала и чистой продуктивности фотосинтеза, синтез хлорофилла, каротиноидов и сахаров, а также преимущество этого препарата перед пестицидом Винцит, КС и биопрепаратом. Под влиянием Нанокремния изменилась структура урожая яровой пшеницы: увеличилось число продуктивных стеблей, колосьев и масса 1000 зерен.

Нашей целью было изучение влияния препарата Нанокремний на фотосинтетическую продуктивность и структуру урожая яровой пшеницы в условиях Орловской области и сравнение его действия с химическим пестицидом и экспериментальным биоактивным препаратом.

Методика. Полевые опыты проводили в 2016-2019 годах (ФГБУ ФНЦ зернобобовых и крупяных культур, пос. Стрелецкое, Орловская обл.) на яровой пшенице (Triticum aestivum L.) сорта Дарья. Сорт включен в Государственный реестр селекционных достижений, допущенных к использованию по Центральному и Центрально-Черноземному регионам (2016 год). Климат территории, где были размещены опытные поля, умеренно континентальный с достаточным количеством тепла и влаги, однако осадки распределяются неравномерно. Почвы опытного участка - темно-серые лесные, среднесуглинистые. Площадь опытной делянки по вариантам 7 м², повторность 4-кратная.

В эксперименте было два контрольных (вода и химический пестицид Винцит, КС) и два опытных (биопрепарат на основе биофлаваноидов гречихи и препарат Нанокремний) варианта. Во всех вариантах семена перед посевом замачивали в течение 2 ч. Обработку по вегетации проводили дважды посредством опрыскивания вегетирующих растений в фазы кущения и выхода в трубку. В контроле семена замачивали в воде из расчета 10 л/т и в препарате Винцит, KC («Cheminova A/S», Франция) из расчета 1,5 л/т при расходе рабочего раствора 10 л/т. При обработке семян экспериментальным биопрепаратом (ФГБОУ ВО «Орловский ГАУ», Россия) его расход составлял 1,56 мл/т, рабочего раствора - 10 л/т; при опрыскивании - соответственно 3,12 мл/га и 200 л. Расход препарата Нанокремний (ООО «НаноКремний», Россия) при предпосевной обработке семян составлял 150 г/т семян, рабочего раствора - 10 л/т; при опрыскивании - соответственно 50 г/га и 200 л/га (27).

Энергию прорастания (процент семян, проросших на 3-и сут) и всхожесть семян (процент семян, проросших на 7-е сут) определяли по ГОСТ 12038-84 «Семена сельскохозяйственных культур. Методы определения всхожести» (М., 2004). Развитие семенной инфекции оценивали по ГОСТ 12044-93 «Семена сельскохозяйственных культур. Методы определения зараженности болезнями» (М., 2011). Заражение семян определяли на 10-е сут в проращивателях. Учитывали общее заражение и выражали в процентах при максимально возможных 100 \% заражения.

Фенологические наблюдения проводили в фазы 2-3 листьев, кущения, выхода в трубку, колошения, цветения, молочной спелости и полной спелости зерна. Чистую продуктивность фотосинтеза определяли по А.А. Ничипоровичу (28) и рассчитывали, исходя из прироста сухой биомассы за период учета, отнесенного к средней площади листьев (29). Площадь листьев измеряли по В.П. Моисееву с соавт. (29). Для исследований отбирали по 10 растений в каждом варианте.

Содержание пигментов в растениях определяли по В.Ф. Гавриленко 
с соавт. (30) после гомогенизации листьев в фарфоровой ступке и экстракции $100 \%$ ацетоном. Концентрацию пигментов в экстрактах измеряли по поглощению при $\lambda=662$ нм (хлорофилл a), $\lambda=644$ нм (хлорофилл b) и $\lambda=440,5$ нм (каротиноиды) (автоматизированный однолучевой спектрофотометр СФ-56, «Ломо-Спектр», Россия).

В таблицах и на рисунках приведены средние арифметические значения $(M)$ и стандартные ошибки средних ( $\pm \mathrm{SEM})$. Достоверность различий определяли по $t$-критерию Стьюдента при $\mathrm{P}=0,95$. Для обработки данных использовали методические рекомендации Б.А. Доспехова (31). В статье представлены полные данные по фотосинтезу, полученные в 2019 году, и данные по урожайности под влиянием Нанокремния и экспериментального биопрепарата по всем четырем годам исследований.

Результаты. В 2019 году фазы развития яровой пшеницы приходились на следующие даты: стадия 2-го листа (всходы) - 6 мая, кущение 20 мая, кущение-начало выхода в трубку - 31 мая, колошение-начало цветения - 13 июня, конец цветения - 23 июня, начало созревания 5 июля.

Минимальное развитие семенной инфекции $(0,8 \%)$ наблюдали в варианте с применением химического протравителя Винцит, КС. В контроле без обработки заражение в разные годы составляло 8,3-12,6 \%, при обработке Нанокремнием - 7,8-9,2 \%, экспериментальным биопрепаратом 6,4-9,5\%.

В лабораторных условиях было установлено, что при предпосевной обработке семян максимальное увеличение энергии прорастания на 18,5\% и всхожести на $5,5 \%$ ( $>0,05)$ по сравнению с контролем наблюдалось в вариантах с Нанокремнием и экспериментальным биопрепаратом. В полевых условиях эта разница составила около $10 \%$. Повышение всхожести семян под влиянием кремния было, по-видимому, связано со стимуляцией роста корней. Регуляторы роста, проникая в растительные клетки, изменяют активность физиологических процессов, прежде всего синтеза гормонов и ферментов, способствуя делению клеток, росту корешка и активации генов аквапоринов (32-34).

Фотосинтетическая продуктивность зависит от физиолого-биохимических процессов, которые определяют величину и качество урожая, но четкого понимания, как эти процессы регулируются и как ими управлять, до сих пор нет $(35,36)$. В обзоре Е. Неyneke с соавт. (37) подчеркивается важная роль метаболических реакций, которые непосредственно не участвуют в фотосинтезе. При этом основное внимание авторы уделяют путям, используемым для улучшения ассимиляции углерода, повышения эффективности фотосинтеза и, следовательно, выхода биомассы (38). Например, рибулозо-1,5-бисфосфаткарбоксилаза/оксигеназа ( $\mathrm{RuBisCo}$ - фундаментальный фермент фиксации углерода чрезвычайно неэффективен, и многие стратегии по улучшению фотосинтетической способности растений сосредоточены на преодолении ограничений работы фермента посредством улучшения активности и регуляции RuBisCo (39).

На опытных участках, начиная со всходов пшеницы, наблюдалось превосходство в развитии растений при обработке Нанокремнием по сравнению с контрольными вариантами (рис. 1). Растения из семян, обработанных экспериментальным биопрепаратом, несколько отставали, но были значительно мощнее контрольных и превосходили их по сухой массе. Наибольшее и существенное превышение контроля на 27-34 \% (p < 0,05) было отмечено в вариантах с Нанокремнием и биопрепаратом. 
Общая площадь листьев на начало периода колошение-начало цветения составила в контроле (вода) $15834,00 \mathrm{~m}^{2}$, в вариантах с использованием Винцита, КС, Нанокремния и экспериментального биопрепарата соответственно 17150,55; 19009,60 и 18141,10 м². Наибольшей площади листьев яровая пшеница достигала в вариантах с Нанокремнием и биопрепаратом, превышая показатель в контроле (вода) на 20,0 и 14,6 \%.

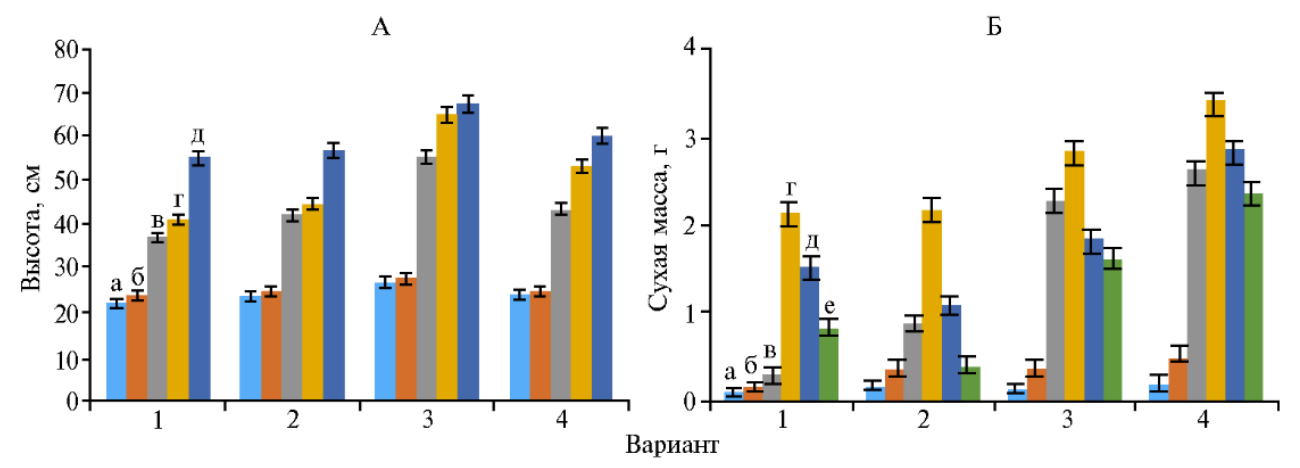

Рис. 1. Высота (А) и сухая масса (Б) растений яровой пшеницы (Triticum aestivum L.) сорта Дарья в фазы 2-го листа (всходы) (а), кущение (б), кущение-начало выхода в трубку (в), колошениеначало цветения (г), конец цветения (д), начало созревания (е) в зависимости от обработки: 1 вода, 2 - Винцит, КС, 3 - Нанокремний, 4 - экспериментальный биопрепарат $(n=10$, $\mathrm{M \pm SEM;} \mathrm{пос.} \mathrm{Стрелецкое,} \mathrm{Орловская} \mathrm{обл.,} 2019$ год).

По мнению А.Т. Мокроносова (40) и С.Н. Никитина (41), при использовании соответствующих агротехнических мероприятий и за более короткие сроки вегетации можно добиться большей продуктивности у растений, которые имеют больше листьев, даже при низкой интенсивности фотосинтеза. Однако, на наш взгляд, при увеличении площади ассимиляционной поверхности стоит учитывать и общую сумму хлорофиллов, а отсюда и питательную ценность урожая. Между тем прирост площади листьев на 1 га за весь вегетационный период, представляющий собой фотосинтетический потенциал посева (ФП), служит показателем продолжительности работы фотосинтетического аппарата. При этом те посевы, у которых ФП составляет 2 млн м ${ }^{2} \cdot$ сут/га, относятся к оптимальным $(42,43)$.

Наши исследования показали, что в течение вегетации ФП яровой пшеницы при применении Нанокремния и экспериментального биопрепарата возрастал за счет увеличения листовой поверхности. В расчете на 1 га ФП составил по вариантам контроль (вода), Винцит, КС, Нанокремний,

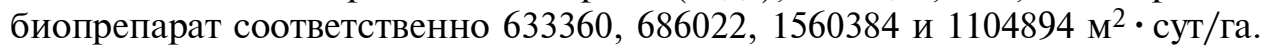

Площадь листовой поверхности связана с накоплением биомассы, которая, по нашим данным (см. рис. 1), была наибольшей в вариантах с Нанокремнием и биопрепаратом.

Использование регуляторов роста и биологических препаратов оказывает влияние на продукционный процесс, индуцирует иммунитет и приводит к созданию экологически чистых продуктов питания (44). Предпосевная обработка семян регуляторами роста положительно сказывается на урожайности и хлебопекарных свойствах продукции, таких как содержание белка и крахмала, количество и качество клейковины и объемная масса зерна (45). У кукурузы, подвергшейся солевому стрессу и холодовому шоку, экзогенное применение салициловой кислоты, маннита и тиомочевины регулирует рост растений и реакции на окислительный стресс, увеличивает скорость роста, индекс листовой поверхности, высоту растений, урожайность зерна, общее накопление сухого вещества $(46,47)$. 
Конечная урожайность зависит и от других факторов, среди которых основополагающую роль играют сорт и почвенно-климатические условия. При этом формирование урожайности определяется чистой продуктивностью фотосинтеза (ЧПФ), зависящей от ассимиляционной поверхности растений (48). Для дальнейшего повышения потенциала урожайности необходимо увеличить общую биомассу, но если солнечный свет в течение вегетационного периода уже полностью используется, то увеличение биомассы требует усиления процессов фотосинтеза $(48,49)$. Концепция более эффективного фотосинтеза для повышения урожайности рассматривалась многими авторами. Так, S.P. Long с соавт. (50) определили такие цели, как улучшение кинетических свойств RuBisCo, модификация культур C3 с приданием им способности осуществлять С4-фотосинтез, улучшение архитектуры купола. Классическим подходом считается изменение устьичной проводимости $(51,52)$.

В наших исследованиях величина ЧПФ прямо зависела от варианта обработки (табл. 1). При обработке яровой пшеницы Нанокремнием и биопрепаратом ЧПФ была выше по сравнению с обоими контролями. Видимо, в обработанных препаратами растениях был больше вклад ассимилирующих органов и меньше расход углеводов на дыхание. Величина ЧПФ у яровой пшеницы изменялась с $6,86 \pm 0,28$ в фазу начала выхода в трубку

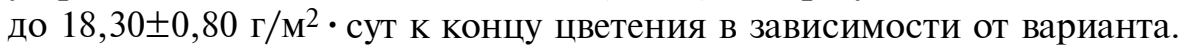

1. Чистая продуктивность фотосинтеза $\left(г / \mathrm{M}^{2} \cdot\right.$ сут) у растений яровой пшеницы (Triticum aestivum L.) сорта Дарья в зависимости от обработки различными препаратами и фазы развития растений $(n=10, M \pm \mathrm{SEM}$; пос. Стрелецкое, Орловская обл., 2019 год)

\begin{tabular}{l|r|rr|r|r}
\hline \multirow{2}{*}{ Вариант } & \multicolumn{5}{|c}{ Фаза развития } \\
\cline { 2 - 6 } & кущение & $\begin{array}{l}\text { кущение-начало } \\
\text { выхода в трубку }\end{array}$ & $\begin{array}{l}\text { колошение-на- } \\
\text { чало цветения }\end{array}$ & $\begin{array}{l}\text { конец } \\
\text { цветения }\end{array}$ & $\begin{array}{l}\text { начало } \\
\text { созревания }\end{array}$ \\
\hline Контроль (вода) & $0,49 \pm 0,02$ & $6,86 \pm 0,28$ & $7,70 \pm 0,35$ & $10,10 \pm 0,37$ & $5,00 \pm 0,24$ \\
Контроль (Винцит, КС) & $1,39 \pm 0,06$ & $7,90 \pm 0,34$ & $8,80 \pm 0,28$ & $9,50 \pm 0,33$ & $6,11 \pm 0,45$ \\
Нанокремний & $1,40 \pm 0,07$ & $8,70 \pm 0,41$ & $14,20 \pm 0,55$ & $18,30 \pm 0,80$ & $10,33 \pm 0,80$ \\
Экспериментальный биопрепарат & $2,29 \pm 0,10$ & $8,20 \pm 0,41$ & $12,20 \pm 0,40$ & $16,90 \pm 0,74$ & $9,30 \pm 0,43$ \\
П р и м е ч а н и е. Подробное описание вариантов см. в разделе «Методика». Фактические значения пока- \\
зателей $t$-критерия Стьюдента превышают табличные при числе степеней свободы df = 9 и вероятности \\
Р = 0,95, что свидетельствует о достоверности полученных различий чистой продуктивности фотосинтеза \\
в сравнении с контрольными значениями. \\
\hline
\end{tabular}

Известно, что увеличение площади листьев посева может снизить фотосинтетическую продуктивность, однако в наших исследованиях этого не произошло. Максимальная площадь листьев в фазу колошения составляла 18000 м²/га, что далеко не соответствует оптимальным значениям (53).

Центральная роль в процессах фотосинтеза принадлежит пигментам, работа которых зависит от климатических и экологических условий $(54,55)$. По мнению Ю.Е. Андриановой с соавт. (35), количество хлорофилла в фазы колошения и выхода в трубку может свидетельствовать о потенциальной урожайности растений, поскольку формирование высокого урожая зависит от размеров ассимиляционного аппарата и времени его функционирования.

Влияние препарата Нанокремний на фотосинтез в наших опытах отражалось и на синтезе пигментов. Их содержание увеличивалось на протяжении всей вегетации на 20-70 \% в зависимости от сроков функционирования листьев (рис. 2, А). Наибольшее количество хлорофилла и каротиноидов приходилось на 13 июля, то есть на фазу колошения-цветения.

Во все периоды развития растения, обработанные Нанокремнием и экспериментальным биопрепаратом, превосходили по содержанию хлоро- 
филла контрольные на 20-30 \%. Надо отметить, что даже в период созревания зерна листья в этих вариантах оставались зелеными, что указывает на более длительную фотосинтетическую активность.

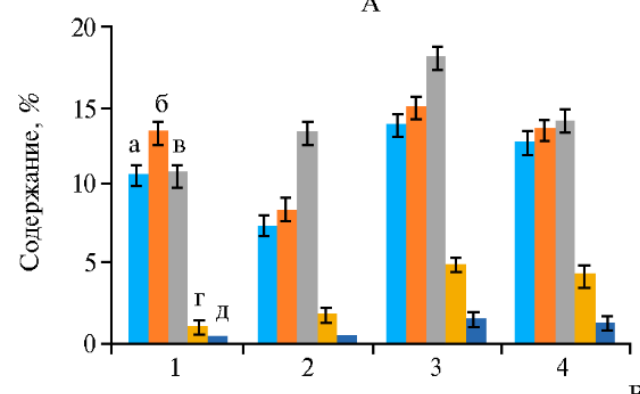

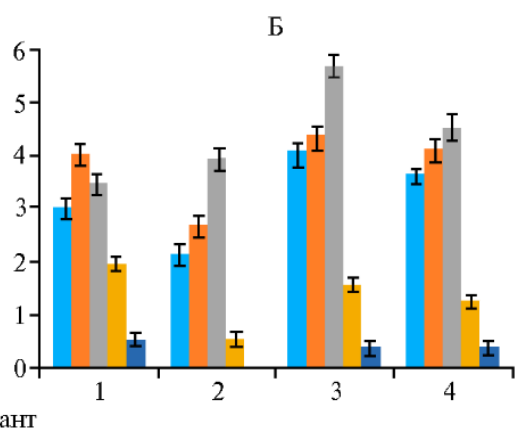

Рис. 2. Синтез хлорофиллов а и b (А) и каротиноидов (Б) у растений яровой пшеницы (Triticum aestivum L.) сорта Дарья в фазы кущения (а), кущения-начала выхода в трубку (б), колошения-начала цветения (в), в конце цветения (г) и в начале созревания (д) в зависимости от обработки: 1 - вода, 2 - Винцит, КС, 3 - Нанокремний, 4 - экспериментальный биопрепарат ( $n=10, M \pm \mathrm{SEM}$; пос. Стрелецкое, Орловская обл., 2019 год).

Каротиноиды поглощают свет в сине-зеленой области солнечного спектра и передают энергию хлорофиллам, тем самым расширяя диапазон длин волн света, который может управлять фотосинтезом. Они служат для повышения общей эффективности фотосинтетических световых реакций и защищают фотосинтезирующие организмы от чрезмерного воздействия света (56). Содержание каротиноидов часто положительно коррелирует с количеством хлорофилла (57). Наши данные подтверждают этот факт (см. рис. 2, Б). Широко известно, что кремний значительно увеличивает рост многих видов растений за счет увеличения фотосинтетической активности, площади листьев и содержания хлорофилла (58-62).

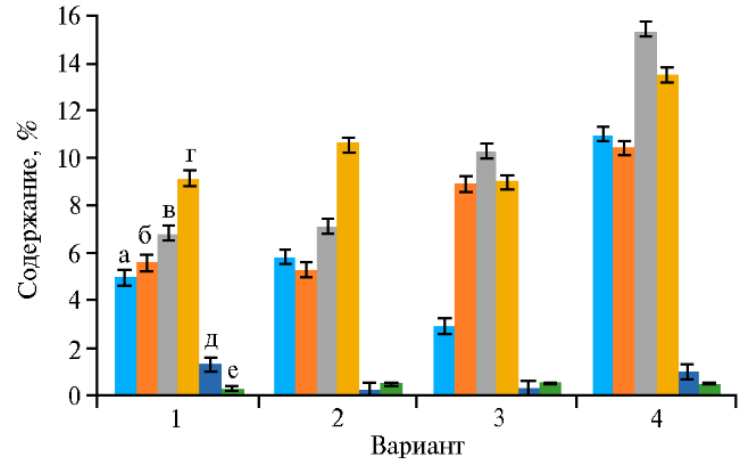

Рис. 3. Накопление сахаров в листьях яровой пшеницы (Triticum aestivum L.) сорта Дарья в фазы 2-го листа (всходы) (а), кущения (б), кущения-начала выхода в трубку (в), колошения-начала цветения (г), в конце цветения (д) и в начале созревания (е) в зависимости от обработки: 1 - вода, 2 - Винцит, КС, 3 - Нанокремний, 4 - экспериментальный биопрепарат $(n=10$,

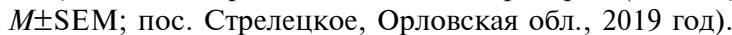

Препарат Нанокремний способствовал увеличению синтеза сахаров в процессе фотосинтеза в меньшей степени, чем экспериментальный биопрепарат, что можно объяснить перераспределением ассимилятов и, вероятно, большим накоплением белков у яровой пшеницы под влиянием Нанокремния (рис. 3). Наше предположение подтверждают данные, показывающие, что минеральные удобрения достоверно увеличивают массовую долю белка и клейковины в зерне яровой пшеницы (63-65). По результатам исследований I. Lavoy с соавт. (66), увеличение содержания белка в семенах пшеницы под действием минеральных удобрений связано с высокой корреляцией между содержанием зернового белка и нитратредуктазной активностью, что подтверждают Z. Тао с соавт. (67). Увеличение количества сахаров в зерне, наблюдаемое в наших иссле- 
дованиях под влиянием экспериментального биопрепарата, возможно, было связано с содержанием в нем салициловой кислоты, положительно влияющей на ассимиляционную активность растений $(68,69)$.

По мнению А.Т. Мокроносова (70), с помощью регуляторов роста и фитогормонов, способствующих изменению оттока ассимилятов из листьев в репродуктивные органы, можно получить наибольший хозяйственный урожай. Регуляторы роста и стимуляторы способствуют повышению иммунитета растений, увеличению урожайности, улучшению качества и получению экологически чистых продуктов питания (53).

Мы установили, что применение Нанокремния на яровой пшенице служит эффективным приемом, повышающим общую урожайность культуры при небольших затратах. В конце вегетации снопы яровой пшеницы, собранные в опытных вариантах, были мощнее контрольных и имели превосходство по размеру колоса. Под влиянием обработки Нанокремнием число продуктивных стеблей увеличивалось на 33,7 , число колосьев - на 38,7 , масса колоса - на 26,8, число зерен в колосе - на 19,2, масса 1000 зерен - на 19,7 \% по сравнению с контролем (вода) (табл. 2). При использовании биопрепарата показатели были несколько ниже, чем в варианте с Нанокремнием, но выше по сравнению с обоими контролями.

2. Структура урожая яровой пшеницы (Triticum aestivum L.) сорта Дарья в зависимости от обработки различными препаратами ( $n=10, M \pm \mathrm{SEM}$; пос. Стрелецкое, Орловская обл., 2019 год)

\begin{tabular}{|c|c|c|c|c|c|c|}
\hline Вариант & $\begin{array}{l}\text { Число продук- } \\
\text { тивных стеблей } \\
\text { на } 1 \text { м², шт. }\end{array}$ & $\begin{array}{l}\text { Длина } \\
\text { колоса, } \\
\text { см }\end{array}$ & $\begin{array}{l}\text { Масса } \\
\text { колоса, г }\end{array}$ & $\begin{array}{l}\text { Число зерен в } \\
\text { колосе, шт. }\end{array}$ & $\begin{array}{l}\text { Масса } 1000 \\
\text { семян, г }\end{array}$ & $\begin{array}{l}\text { Число ко- } \\
\text { лосьев, шт. }\end{array}$ \\
\hline Контрол & $326 \pm 11,2$ & $8,2 \pm 0,37$ & & & $7 \pm 1,49$ & \\
\hline Конт & &, $3 \pm$ & & & & \\
\hline Нано & & $9,0 \pm 0,43$ & & & & \\
\hline & & & & & & \\
\hline & 344 & - & & & & $319 \pm 12,7$ \\
\hline \multicolumn{7}{|c|}{$\begin{array}{l}\text { П р и м е ч а и е. Подробное описание вариантов см. в разделе «Методика». Фактические значения пока- } \\
\text { зателей } t \text {-критерия Стьюдента превышают табличные при числе степеней свободы df = } 9 \text { и вероятности } \\
\mathrm{P}=0,95 \text {, что свидетельствует о достоверности полученных различий чистой продуктивности фотосинтеза } \\
\text { в сравнении с контрольными значениями. }\end{array}$} \\
\hline
\end{tabular}

Урожайность пшеницы под влиянием Нанокремния повышалась за счет увеличения как числа зерен в колосе, так и их массы (табл. 3). При обработке Винцитом, КС урожайность увеличивалась на $8 \%$ по сравнению с контролем без обработки, за исключением 2019 года (только на 5 \%), а под влиянием Нанокремния и биопрепарата ее прирост составил 9-19\%.

3. Урожайность яровой пшеницы (Triticum aestivum L.) сорта Дарья в зависимости от обработки различными препаратами за четыре года исследований ( $n=10, M \pm \mathrm{SEM}$; пос. Стрелецкое, Орловская обл.)

\begin{tabular}{|c|c|c|c|c|c|c|c|c|}
\hline \multirow{2}{*}{ Вариант } & \multicolumn{4}{|c|}{ Урожайность, ц/га } & \multicolumn{4}{|c|}{ Прибавка к контролю (вода), \% } \\
\hline & 2016 & 2017 & 2018 & 2019 & 2016 & 2017 & 2018 & 2019 \\
\hline Контроль (вода) & $28,9 \pm 1,38$ & $38,2 \pm 1,61$ & $41,3 \pm 2,04$ & $45,1 \pm 2,00$ & & & & \\
\hline Контроль (Винцит, КС) & $31,4 \pm 1,20$ & $41,4 \pm 0,91$ & $44,5 \pm 2,11$ & $47,3 \pm 2,01$ & 8,65 & 8,40 & 7,80 & 4,88 \\
\hline Нанокремний & $33,7 \pm 1,45$ & $43,7 \pm 2,03$ & $45,1 \pm 2,19$ & $49,4 \pm 1,91$ & 16,61 & 14,40 & 9,20 & 9,53 \\
\hline $\begin{array}{l}\text { Экспериментальный } \\
\text { биопрепарат } \\
\text { HCP }_{05}\end{array}$ & $\begin{array}{c}34,5 \pm 1,55 \\
1,2\end{array}$ & $\begin{array}{c}43,9 \pm 2,07 \\
1,4\end{array}$ & $\begin{array}{c}45,3 \pm 1,71 \\
1,2\end{array}$ & $\begin{array}{c}48,9 \pm 2,16 \\
0,9\end{array}$ & 19,01 & 14,90 & 9,20 & 8,43 \\
\hline
\end{tabular}

П р и м е ч а н и е. Подробное описание вариантов см. в разделе «Методика». Фактические значения показателей $t$-критерия Стьюдента превышают табличные при числе степеней свободы $\mathrm{df}=9$ и вероятности $\mathrm{P}=0,95$, что свидетельствует о достоверности полученных различий чистой продуктивности фотосинтеза в сравнении с контрольными значениями.

Таким образом, препарат Нанокремний по действию на яровую пшеницу сорта Дарья оказался эффективнее по сравнению с химическим 
пестицидом Винцит, КС, но мало отличался от нового экспериментального биопрепарата, созданного на основе биофлаваноидов гречихи. Обработка семян перед посевом Нанокремнием и биопрепаратом повышала энергию прорастания на $18,5 \%$ и всхожесть на $5,5 \%(\mathrm{p}<0,05)$ по сравнению с контрольными вариантами (вода и Винцит, КС). Превосходство Нанокремния перед контрольными вариантами отразилось на высоте растений, числе и площади листьев, а также на фотосинтетическом потенциале и показателях чистой продуктивности фотосинтеза (ЧПФ), количестве хлорофиллов и каротиноидов. Показатели ЧПФ при обработке Нанокремнием были выше контрольных на 60-80 \% (вода) и 22,2 \% (Винцит, КС). Под влиянием Нанокремния и биопрепарата синтез пигментов увеличился на 20-30 \%. Биопрепарат в большей степени влиял на синтез сахаров, чем Нанокремний, что можно объяснить разницей перераспределения ассимилятов и большим накоплением белков в растениях под влиянием кремния. Обработка Нанокремнием привела к увеличению числа семян в колосе и массы 1000 семян по сравнению с контрольными вариантами. Преимущество перед биоактивным препаратом было несущественным. Число продуктивных стеблей в варианте с Нанокремнием увеличивалось на 33,7 , число колосьев - на 38,7, масса колоса - на 26,8, число зерен в колосе - на 19,2, масса 1000 зерен - на 19,7 \% по сравнению с контролем $(\mathrm{p}<0,05)$. Показатели по биопрепарату были несколько ниже, чем по Нанокремнию, но выше контрольных. Урожайность пшеницы на протяжении четырех лет под влиянием обработки Нанокремнием и биопрепаратом по сравнению с контрольными вариантами возрастала на 9,0-16,6 \%.

\section{ЛИТЕРАТ У РА}

1. Food and Agriculture Organization Corporate Statistical Database. Режим доступа: http://www.fao.org/faostat/ru/\#data/QC. Без даты.

2. Khoury C.K., Bjorkman A.D., Dempewolf H., Ramirez-Villegas J., Guarino L., Jarvis A., Rieseberg L.H., Struik P.C. Increasing homogeneity in global food supplies and the implications for food security. Proceedings of the National Academy of Sciences, 2014, 111(11): 4001-4006 (doi: 10.1073/pnas.1313490111).

3. Johnson V.A., Briggle L.W., Axtel J.D., Bauman L.F., Leng E.R., Johnston T.H. Grain crops. In: Protein resources and technology /M. Milner, N.S. Scrimshaw, D.I.C. Wang (eds.). AVI Publishin, Westport, CT, USA, 1978: 239-255.

4. Giraldo P., Benavente E., Manzano-Agugliaro F., Gimenez E. Worldwide research trends on wheat and barley: a bibliometric comparative analysis. Agronomy, 2019, 9(7): 352 (doi: 10.3390/agronomy9070352).

5. Singh R.P., Singh P.K., Rutkoski J., Hodson D.P., He X., Jorgensen L.N., Hovmøller M.S., Huerta-Espino J. Disease impact on wheat yield potential and prospects of genetic control. Annual Review of Phytopathology, 2016, 54: 303-322 (doi: 10.1146/annurev-phyto-080615-095835).

6. Hawkesford M.J., Araus J.-L., Park R., Calderini D., Miralles D., Shen T., Zhang J., Parry M.A.J. Prospects of doubling global wheat yields. Food and Energy Security, 2013, 2(1): 34-48 (doi: 10.1002/fes3.15).

7. Slafer G.A., Savin R., Sadras V.O. Coarse and fine regulation of wheat yield components in response to genotype and environment. Field Crops Research, 2014, 157: 71-83 (doi: 10.1016/j.fcr.2013.12.004).

8. Trnka M., Rötter R.P., Ruiz-Ramos M., Kersebaum K.C., Olesen J.E., Žalud Z., Semenov M.A. Adverse weather conditions for European wheat production will become more frequent with climate change. Nature Climate Change, 2014, 4(7): 637-643 (doi: 10.1038/NCLIMATE2242).

9. Wang J., Vanga S.K., Saxena R., Orsat V., Raghavan V. Effect of climate change on the yield of cereal crops: a review. Climate, 2018, 6(2): 41 (doi: 10.3390/cli6020041).

10. Yavaș İ., Ünay A. The role of silicon under biotic and abiotic stress conditions. Türkiye Tarımsal Araştırmalar Dergisi, 2017, 4(2): 204-209 (doi: 10.19159/tutad.300023).

11. Cooke J., Leishman M.R. Consistent alleviation of abiotic stress with silicon addition: a metaanalysis. Functional Ecology, 2016, 30(8): 1340-1357 (doi: 10.1111/1365-2435.12713). 
12. Mir R.A., Bhat K.A., Shah A.A., Zargar S.M. Role of silicon in abiotic stress tolerance of plants. In: Improving abiotic stress tolerance in plants. CRC Press, 2020 (doi: 10.1201/9780429027505-15).

13. Frew A., Weston L.A., Reynolds O.L., Gurr G.M. The role of silicon in plant biology: a paradigm shift in research approach. Annals of Botany, 2018, 121(7): 1265-1273 (doi: 10.1093/aob/mcy009).

14. Abdel-Haliem M.E.F., Hegazy H.S., Hassan N.S., Naguib D.M. Effect of silica ions and nano silica on rice plants under salinity stress. Ecological Engineering, 2017, 99: 282-289 (doi: 10.1016/j.ecoleng.2016.11.060).

15. Luyckx M., Hausman J.-F., Lutts S., Guerriero G. Silicon and plants: current knowledge and technological perspectives. Front. Plant Sci., 2017, 8: 411 (doi: 10.3389/fpls.2017.00411).

16. Liang Y., Nikolic M., Bélanger R., Gong H., Song A. Silicon uptake and transport in plants: physiological and molecular aspects. In: Silicon in agriculture /Y. Liang, M. Nicolic, R. Bélanger, H. Gong, A. Song (eds). Springer, Dordrecht, 2015: 69-82 (doi: 10.1007/978-94-017-9978-2).

17. Козлов А.В., Куликова А.Х., Яшин Е.А. Роль и значение кремния и кремнийсодержащих веществ в агроэкосистемах. Вестник Мининского университета, 2015, 2: 23-31.

18. Al-Aghabary K., Zhu Z., Shi Q. Influence of silicon supply on chlorophyll content, chlorophyll fluorescence and anti-oxidative enzyme activities in tomato plants under salt stress. Journal of Plant Nutrition, 2005, 27(12): 2101-2115 (doi: 10.1081/PLN-200034641).

19. Molero G., Joynson R., Pinera-Chavez F.J., Gardiner L., Rivera-Amado C., Hall A., Reynolds M.P. Elucidating the genetic basis of biomass accumulation and radiation use efficiency in spring wheat and its role in yield potential. Plant Biotechnology Journal, 2019, 17(7): 1276-1288 (doi: 10.1111/pbi.13052).

20. Richards R.A. Selectable traits to increase crop photosynthesis and yield of grain crops. Journal of Experimental Botany, 2000, 51(Suppl. 1): 447-458 (doi: 10.1093/jexbot/51.suppl_1.447).

21. Curtis T., Halford N.G. Food security: the challenge of increasing wheat yield and the importance of not compromising food safety. Annals of Applied Biology, 2014, 164(3): 354-372 (doi: 10.1111/aab.12108).

22. Косачев И.А., Чернышков В.Н. Влияние кремнийсодержащего препарата «Нанокремний» на рост, развитие и продуктивность сельскохозяйственных культур в условиях Алтайского края. Вестник Алтайского государственного аграрного университета, 2018, 9(167): 23-28.

23. Семина С.А., Остробородова Н.И. Перспективы применения препарата нанокремний на посевах яровой пшеницы. Мат. Межд. науч.-практ. конф., посвященной 80-летию д.с.х.н., проф. Созырко Х.Д. «Актуальные вопросы применения удобрений в сельском хозяйстве». Владикавказ, 2017: 63-65.

24. Серкова О.П., Жандарова С.В. Влияние нанокремния на урожайность зерна яровой пшеницы в условиях умеренно засушливой колочной степи Алтайского края. Mam. XIV Межд. науч.-практ. конф. «Аграрная наука - сельскому хозяйству». Барнаул, 2019, кн. 2: 246-247.

25. Мнатсаканян А.А., Чуварлеева Г.В. Эффективность препарата нанокремний на озимой пшенице. Мат. Межд. науч.-практ. конф. молодых ученых и специалистов «Фундаментальные основы управления селекционным процессом создания новых генотипов растений с высокими хозяйственно ценными признаками продуктивности, устойчивости к био- и абиострессорам». Орел, 2017: 135-139.

26. Чуварлеева Г.В., Мнатсаканян А.А. Влияние препарата нанокремний на урожайность и качество озимого ячменя. Мат. науч.-практ. конф., посвященной 110-летию со дня рождения академика В.И. Шемпеля. Жодино, 2018: 114-116.

27. Павловская Н.Е., Горькова И.В., Гагарина И.Н., Бородин Д.Б., Борзенкова Г.А. Средство для предпосевной обработки семян гороха. RU 2463759 C1 МПК A01C 1/06, А01C 1/08. Федеральное государственное образовательное учреждение высшего профессионального образования «Орловский государственный аграрный университет» (РФ). № 2011117691/13. Заявл. 03.05.2011. Опубл. 20.10.2012. Бюл. № 29.

28. Ничипорович А.А., Строгонова Л.Е., Чмора С.Н., Власова М.П. Фотосинтетическая деятельность растений в посевах (Методы и задачи учета в связи с формированием урожаев). M., 1961.

29. Моисеев В.П., Решецкий Н.П. Физиология и биохимия растений: метод. указ. Горки, 2009.

30. Гавриленко В.Ф., Ладыгина М.Е., Хандобина Л.М. Большой практикум по физиологии растений /Под ред. Б.А. Рубина. М., 1975.

31. Доспехов Б.А. Методика полевого опыта (с основами статистической обработки результатов исследований). М., 1985.

32. Westfall C.S., Muehler A.M., Jez J.M. Enzyme action in the regulation of plant hormone responses. Journal of Biological Chemistry, 2013, 288(27): 19304-19311 (doi: 10.1074/jbc.R113.475160).

33. Zhang Y., Xu S., Ji F., Hu Y., Gu Z., Xu B. Plant cell wall hydrolysis process reveals structureactivity relationships. Plant Methods, 2020, 16: 147 (doi: 10.1186/s13007-020-00691-5).

34. Liu P., Yin L., Wang S., Zhang M., Deng X., Zhang S., Tanaka K. Enhanced root hydraulic 
conductance by aquaporin regulation accounts for silicon alleviated salt-induced osmotic stress in Sorghum bicolor L. Environmental and Experimental Botany, 2015, 111: 42-51 (doi: 10.1016/j.envexpbot.2014.10.006).

35. Андрианова Ю.Е., Тарчевский И.А. Хлорофилл и продуктивность растений. М., 2000.

36. Орт Д., Меландри Б.А., Юнге В., Уитмарш Дж. Фотосинтез. Т. 2 /Под ред. Д.Р. Говинджи. М., 1987.

37. Heyneke E., Fernie A.R. Metabolic regulation of photosynthesis. Biochem. Soc. Trans., 2018, 46(2): 321-328 (doi: 10.1042/BST20170296).

38. Timm S. The impact of photorespiration on plant primary metabolism through metabolic and redox regulation. Biochem. Soc. Trans., 2020, 48(6): 2495-2504 (doi: 10.1042/BST20200055).

39. Andralojc P.J., Carmo-Silva E., Degen G.E., Parry M.A.J. Increasing metabolic potential: Cfixation. Essays Biochem., 2018, 62(1): 109-118 (doi: 10.1042/EBC20170014).

40. Мокроносов А.Т. Фотосинтез и продукционный процесс. В сб.: Физиология растений на службе продовольственной программы СССР. М., 1988, ч. 2: 3-18.

41. Никитин С.Н. Фотосинтетическая деятельность растений в посевах и динамика ростовых процессов при применении биологических препаратов. Успехи современного естествознания, 2017, 1: 33-38.

42. Ничипорович А.А. Реализация регуляторной функции света и жизнедеятельности растений как целого и в его продуктивности. В сб.: Фоторегуляция метаболизма и морфогенеза растений. М., 1975: 228-244.

43. Синеговская В.Т., Абросимова Т.Е. Активизация фотосинтетической деятельности яровой пшеницы при длительном применении удобрений. Вестник Российской академии сельскохозяйственных наук, 2006, 5: 43-45.

44. Тимошенко Э.В. Действие биопрепаратов на показатели фотосинтеза и урожайность яровой пшеницы в Амурской области. МНИЖ Международный научно-исследовательский журнал, 2015, 41(10-3): 68-70 (doi: 10.18454/IRJ.2015.41.092).

45. Isaychev V., Andreev N., Bogapova M. The influence of growth regulators on the productive capacity of spring wheat. BIO Web Conf. Int. Scientific-Practical Conf. Agriculture and Food Security: Technology, Innovation, Markets, Human Resources. Ulyanovsk, 2020, 17: 5 (doi: 10.1051/bioconf/20201700106).

46. Waqas M.A., Khan I., Akhter M.J., Noor M.A., Ashraf U. Exogenous application of plant growth regulators (PGRs) induces chilling tolerance in short-duration hybrid maize. Environmental Science and Pollution Research, 2017, 24: 11459-11471 (doi: 10.1007/s11356-017-8768-0).

47. Kaya C., Sonmez O., Aydemir S., Ashraf M., Dikilitas M. Exogenous application of mannitol and thiourea regulates plant growth and oxidative stress responses in salt-stressed maize (Zea mays L.). Journal of Plant Interactions, 2013, 8(3): 234-241 (doi: 10.1080/17429145.2012.725480).

48. Li X., Schmid B., Wang F., Paine C.E.T. Net assimilation rate determines the growth rates of 14 species of subtropical forest trees. PLoS ONE, 2016, 11(3): e0150644 (doi: 10.1371/journal.pone.0150644).

49. Evans J.R. Improving photosynthesis. Plant Physiology, 2013, 162(4): 1780-1793 (doi: 10.1104/pp.113.219006).

50. Long S.P., Zhu X.-G., Naidu S.L., Ort D.R. Can improvement in photosynthesis increase crop yields? Plant, Cell \& Environment, 2006, 29(3): 315-330 (doi: 10.1111/j.1365-3040.2005.01493.x).

51. Condon A.G., Farquhar G.D., Richards R.A. Genotypic variation in carbon isotope discrimination and transpiration efficiency in wheat: leaf gas-exchange and whole plant studies. Australian Journal of Plant Physiology, 1990, 17(1): 9-22 (doi: 10.1071/PP9900009)

52. Rebetzke G.J., Rattey A.R., Farquhar G.D., Richards R.A., Condon A.G. Genomic regions for canopy temperature and their genetic association with stomatal conductance and grain yield in wheat. Functional Plant Biology, 2013, 40(1): 14-33 (doi: 10.1071/FP12184).

53. Ничипорович А.А., Асроров К.А. О некоторых принципах оптимизации фотосинтетической деятельности растений в посевах. В кн.: Фотосинтез и использование солнечной энергии. Л., 1971: 5-18.

54. Myśliwa-Kurdziel B., Latowski D., Strzałka K. Chapter Three. Chlorophylls c - Occurrence, synthesis, properties, photosynthetic and evolutionary significance. Advances in Botanical Research, 2019, 90: 91-119 (doi: 10.1016/bs.abr.2019.04.002).

55. Головко Т.К., Табаленкова Г.Н., Дымова О.В. Пигментный комплекс растений Приполярного Урала. Ботанический журнал, 2007, 92: 1732-1742.

56. Hashimoto H., Uragami C., Cogdell R.J. Carotenoids and photosynthesis. In: Carotenoids in nature. Subcellular biochemistry, vol. 79 /C. Stange (eds.). Springer, Cham, 2016: 111-139 (doi: 10.1007/978-3-319-39126-7 4).

57. Иванов Л.А., Иванова Л.А., Ронжина Д.А., Юдина П.К. Изменение содержания хлорофиллов и каротиноидов в листьях степных растений вдоль широтного градиента на Южном Урале. Физиология растений, 2013, 60(6): 856-864 (doi: 10.7868/S0015330313050072).

58. Bae E.J., Lee K.S., Huh M.R., Lim C.S. Silicon significantly alleviates the growth inhibitory effects of $\mathrm{NaCl}$ in salt-sensitive «Perfection» and «Midnight» Kentucky bluegrass (Poa 
pratensis L). Hortic. Environ. Biotechnol., 2012, 53: 477-483 (doi: 10.1007/s13580-012-0094-3).

59. Lee S.K., Sohn E.Y., Hamayun M., Yoon J.Y., Lee I.J. Effect of silicon on growth and salinity stress of soybean plant grown under hydroponic system. Agroforest Syst., 2010, 80: 333-340 (doi: 10.1007/s10457-010-9299-6).

60. Al-Aghabary K., Zhu Z., Shi Q. Influence of silicon supply on chlorophyll content, chlorophyll fluorescence and anti-oxidative enzyme activities in tomato plants under salt stress. Journal of Plant Nutrition, 2005, 27(12): 2101-2115 (doi: 10.1081/PLN-200034641).

61. Romero-Aranda M.R., Jurado O., Cuartero J. Silicon alleviates the deleterious salt effect on tomato plant growth by improving plant water status. J. Plant Physiol., 2006, 163(8): 847-855 (doi: 10.1016/j.jplph.2005.05.010).

62. Murillo-Amador B., Yamada S., Yamaguchi T., Rueda-Puente E., Ávila-Serrano N., GarcíaHernández J.L., López-Aguilar R., Troyo-Diéguez E., Nieto-Garibay A. Influence of calcium silicate on growth, physiological parameters and mineral nutrition in two legume species under salt stress. Journal of Agronomy and Crop Science, 2007, 193(6): 413-421 (doi: 10.1111/j.1439037X.2007.00273.x).

63. Artyszak A. Effect of silicon fertilization on crop yield quantity and quality - a literature review in Europe. Plants, 2018, 7(3): 54 (doi: 10.3390/plants7030054).

64. Виноградова В.С., Мартынцева А.А., Казарин С.Н. Влияние гуминовых и микроудобрений на урожайность яровой пшеницы. Земледелие, 2015, 1: 32-34.

65. Богомазов С.В., Левин А.А., Ткачук О.А., Лянденбурская А.В. Урожайность и качество зерна яровой мягкой пшеницы в зависимости от применения гуминового и минеральных удобрений. Нива Поволжья, 2019, 3(52): 68-73.

66. Lavoy I., Croy R., Hageman H. Relationship of nitrate reductase activity to grain protein production in wheat. Crop Science, 1970, 10(3): 280-285 (doi: 10.2135/cropsci1970.0011183X001000030021x).

67. Tao Z., Chang X., Wang D., Wang Y., Ma S., Yang Y., Zhao G. Effects of sulfur fertilization and short-term high temperature on wheat grain production and wheat flour proteins. The Crop Journal, 2018, 6(4): 413-425 (doi: 10.1016/j.cj.2018.01.007).

68. Khursheed M.Q. Effect of foliar application of Salicylic acid on growth, yield components and chemical constituents of Wheat (Triticum aestivum L. var. Cham 6). $5^{\text {th }}$ Scientific Conference of College of Agriculture. Article Salahaddin University. Erbil, 2011. Режим доступа: https://www.researchgate.net/publication/313968252. Без даты.

69. Janda T., Gondor O.K., Yordanova R., Szalai G., Pál M. Salicylic acid and photosynthesis: signalling and effects. Acta Physiol. Plant, 2014, 36: 2537-2546 (doi: 10.1007/s11738-0141620-y).

70. Мокроносов А.Т. Онтогенетический аспект фотосинтеза. М., 1981.

ФГБОУ ВО Орловский ГАУ им. Н.В. Парахина,

302019 Россия, г. Орел, ул. Генерала Родина, 69,

e-mail: khoroshilov@nano-si.ru, ninel.pavlovsckaya@yandex.ru $\bowtie$,

bioogau@mail.ru, as290186@yandex.ru
Поступила в редакцию 13 июля 2020 года

Sel'skokhozyaistvennaya biologiya [Agricultural Biology], 2021, V. 56, № 3, pp. 487-499

\section{A NANOSILICON PREPARATION IS SUPERIOR TO A BIOLOGICAL PREPARATION AND A CHEMICAL PREPARATION IN ACTIVITY TOWARDS PHOTOSYNTHETIC PRODUCTIVITY AND YIELD PARAMETERS OF SPRING WHEAT}

\section{A.A. Khoroshilov, N.E. Pavlovskaya ${ }^{凶}$, D.B. Borodin, I.V. Yakovleva}

Parakhin Orel State Agrarian University, 69, ul. Generala Rodina, Orel, 302019 Russia, e-mail khoroshilov@nano-si.ru, ninel.pavlovsckaya@yandex.ru ( $₫$ corresponding author), bioogau@mail.ru, as290186@yandex.ru ORCID:

Khoroshilov A.A. orcid.org/0000-0001-5525-9560 Pavlovskaya N.E. orcid.org/0000-0001-7246-5059 The authors declare no conflict of interests Received July 13, 2020

Borodin D.B. orcid.org/0000-0002-3634-5882

Yakovleva I.V. orcid.org/0000-0002-6070-7110

doi: 10.15389 /agrobiology.2021.3.487eng

\section{Abstract}

Wheat is widely used as a food, technical and feed crop. Increased wheat yields can be achieved by mitigating biotic and abiotic stresses using a variety of technologies that include trace elements and growth regulators. Nanosilicon microfertilizer (NanoSilicon LLC, Russia) is an environmentally friendly product containing $50 \%$ of pure colloidal-sized crystalline silicon. This work, for the first time, confirms the positive effect of the Nanosilicon preparation on photosynthetic potential and 
the net productivity of photosynthesis, the synthesis of chlorophyll, carotenoids and sugars and shows an advantage of Nanosilicon over the pesticide Vincite and an experimental biological product. Under the influence of Nanosilicon, the component structure of the spring wheat yield changed, namely, the number of productive stems, ears and 1000 grain weight increased. Our goal was to examine the effect of Nanosilicon preparation on spring wheat photosynthetic productivity and yield components in the conditions of the Orel region and to compare the effect of Nanosilicon with that of a chemical pesticide and a bioactive preparation. The experiment design included four treatments of spring wheat (Triticum aestivum L.) cv. Darya seeds (Federal Research Center for Grain-Legumes and Cereals, Streletskoe village, Oryol region, 2016-2019). The seeds were soaked for 2 hours before sowing in water, in chemical pesticide Vinzit (two controls), in a novel biological product based on buckwheat bioflavonoids, and in Nanosilicon concentrate (tests). During vegetation, the control and test treatments were twice applied to the growing plants at tillering and at stem extension phases. The energy of seed germination and germination rate were determined, the development of seed infections was assessed. The phenological phases (three leaves, tillering, stem extension, earing, flowering, milk ripeness, and full ripeness of the grain) were recorded. Photosynthetic potential (PP), photosynthetic productivity and net photosynthetic productivity (NPP) were evaluated, leaf area and the pigment content were measured. It was found that pre-sowing treatment of spring wheat seeds with Nanosilicon contributed to an $18.5 \%$ increase in germination energy and a $5.5 \%$ increase in germination rate as compared to the control treatments. Due to the Nanosilicon application, the plants were taller, resulting in more leaves until the end of the growing season, which indicates a longer leaf life compared to controls. The leaf area was $20.0 \%$ larger at the earing-flowering period compared to the control (water), that was, $14.6 \%$ larger for the biopreparation and $8.3 \%$ larger for the pesticide Vincit. Photosynthetic capacity for control (water), Vincit, Nanosilicon, and the biopreparation was 633360, 686022, 1560384, and $1104894 \mathrm{~m}^{2} \cdot$ day/ha, respectively. NPP value for Nanosilicon was greater as compared to the controls, by $60-80 \%$ for water and by $22.2 \%$ for Vincit. The amounts of chlorophylls and carotenoids in plants were the greatest at the earing-flowering phase. Under the influence of Nanosilicon and the biological preparation, the synthesis of pigments increased by 20-30\% compared to the controls. Nanosilicon contributed to an increase in the synthesis of sugars in the process of photosynthesis to a lesser extent than the biological product, which can be explained by the difference in the distribution of assimilates and a large accumulation of proteins. The advantages of the Nanosilicon over the bioactive preparation in the number of grains and the 1000-seed weight were minor. Under the effect of Nanosilicon, the number of productive stems increased by $33.7 \%$, the number of ears by $38.7 \%$, the ear weight by $26.8 \%$, the number of grains per ear by 19.2 ear, and the 1000 -grain weight by $19.7 \%$ as compared to the control. These indicators for the bioactive preparation were slightly lower than for Nanosilicon, but higher than in control treatments. For four years, the grain yield under the influence of Vincite was approximately $8 \%$ higher compared to the control (water) and from 9 to $16.6 \%$ higher due to Nanosilicon and the bioactive preparation.

Keywords: spring wheat, Nanosilicon, biological product, germination energy, germination rate, net photosynthetic productivity, yield components. 